\title{
THE SPATIAL RESCALING OF THE DEVELOPMENTAL STATE IN BRAZIL
}

\author{
reescalonamento espacial do estado desenvolvimentista no Brasil
}

\author{
Marcos Barcellos de Souza *
}

\begin{abstract}
Resumo
O presente trabalho pretende oferecer uma contribuição ao debate sobre economia política regional e urbana no Brasil ao explorar as relações entre o Estado, as instituições e as escalas espaciais na produção e regulação do desenvolvimento espacial desigual no país. Para tanto, com base em contribuições recentes na Geografia anglo-saxã, busca-se examinar as tensões e crises do Estado desenvolvimentista em suas estratégias e projetos espaciais. Nesse sentido, pretende-se adaptar alguns dos pressupostos teóricos ao contexto brasileiro, de modo a incorporar sua forma de Estado e processos de reescalonamentos específicos. Adota-se uma metodologia processual para analisar como a urbanização e o desenvolvimento regional acabam criando mecanismos próprios de deslocamento e de geração de crises regulatórias, assim como estratégias correspondentes de intervenção política para resolvê-las. Nesse trabalho, partimos da ideia de que a a hegemonia é disputada em múltiplas escalas, o que permite estabelecer as relações entre mudanças no bloco hegemônico e nas formas espaciais do Estado.
\end{abstract}

Palavras-chaves: Estado Desenvolvimentista; Escalas Espaciais; Reescalonamento.

\begin{abstract}
This paper aims to contribute to the debate on the urban and regional political economy in Brazil by exploring the relationships between the State, the institutions and spatial scales in the production and regulation of uneven spatial development in the country. Therefore, based on recent contributions in Anglo-Saxon geography, the tensions and crises of the developmental State are examined through their spatial strategies and projects. In this sense, the intention is to adapt some of the theoretical background to the Brazilian context in order to incorporate the form of its State and specific rescaling processes. A procedural methodology is used to analyze how urbanization and regional development end up creating their own mechanisms of displacement and generation of regulatory crises, as well as the corresponding strategies of political intervention to resolve them. This study is based on the idea that hegemony is contested on multiple scales, which allows the relationship between changes in the hegemonic bloc and the spatial forms of the State to be established.
\end{abstract}

Key words: Developmental State; Spatial Scales; Rescaling.

\section{Resumen}

Este trabajo pretende ofrecer una contribución al debate sobre la economía política urbana y regional en Brasil para explorar las relaciones entre las instituciones estatales y las escalas espaciales en la producción y regulación del desarrollo espacial desigual en el país. Para ello, sobre la base de las contribuciones recientes a la Geografía anglosajona, buscamos analizar las tensiones y crisis en las estrategias y proyectos de desarrollo espacial del Estado. En este sentido, tenemos la intención de adaptar algunos de los supuestos teóricos para el contexto brasileño, con el fin de incorporar su forma de Estado y los procesos de rescalonamientos específicos. Adoptamos una metodología de procedimiento para analizar cómo la urbanización y el desarrollo regional terminan creando sus propios mecanismos de desplazamiento y generación de las crisis de regulación, así como de las correspondientes estrategias de intervención política para resolverlos. En este trabajo, se parte de la idea de que la hegemonía es disputada en múltiples escalas, lo que permite establecer las relaciones entre los cambios en el bloque hegemónico y las formas espaciales del Estado.

Palabras Cles: Estado Desarrolista; Escalas Espaciales; Rescalonamientos.

(*) Lecturer, Doctor of the Federal University of ABC (Universidade Federal do ABC) - Campus São Bernardo do Campo. Rua Arcturus, 3 - CEP: 09606-070, São Bernardo do Campo (SP), Brasil. Tel: (055 xxxxxxxxxxxx) - barcellos.marcos@hotmail.com 


\section{INTRODUCTION}

This paper aims to contribute to the debate on the urban and regional political economy in Brazil by exploring the relationships between the State, the institutions and spatial scales in the production and regulation of the uneven spatial development in the country. The theme of spatial scales has become more relevant in discussions on regional and urban planning in Brazil in debates that include the critique of endogenous local development, the evolution of urban and metropolitan governance and the different capacity the actors have to exercise power in the territory. Although this new relevance is positive, care needs to be taken so that the debate on scales does not take on a normative or essentialist aspect. In other words, we believe that discussions should prioritize relations between the scales and especially the processes that cause changes in these relationships (rescaling).

A rigorous reflection on the production of the scales is needed and if the regional issue is a question of State (EGLER, 2010), than it is necessary to deepen the understanding of the spatial rescaling of the State and analyze the theoretical assumptions and concrete manifestations of this phenomenon in Brazil. As will be demonstrated below, these manifestations have particular properties in time and space, so that a mere transposition of the experiences observed in other contexts can be problematic.

First, there is the difference in the very form of the State in relation to what Jessop (2002) classified as Keynesian Welfare National State (KWNS), making it impossible to find some kind of "spatial Keynesianism" in Brazil. The form of the Brazilian (Developmental) State would necessarily need to accept its reality of underdevelopment. This implies that the trends towards crisis of this State form and the regime of spatial regulation take on peculiar characteristics.

The evolution of regulatory projects and state spatiality is analyzed using the procedural methodology adopted by Neil Brenner (2004), according to which the object of research is not a given scalar configuration of the state apparatus, nor specific scales of State power. Our interest is to understand the spatial and scalar selectivity of the State as an expression, a means and a product of political strategies. Thus, like Brenner, we will use the Strategic-Relational Approach, which has been developed and perfected by Bob Jessop (2008) for several years.

Following the procedural methodology proposed by Brenner (2004), there is an analysis of how urbanization and regional development end up creating specific forms of displacement and generation of regulatory crises, as well as corresponding strategies of political intervention to resolve them. In this sense, emphasis will be given to the co-evolution of the strategies and spatial projects of the State and its relationship with the political forces and the hegemonic bloc through what is known as "spatial developmentalism". In turn, this development is intertwined with the changes in direction and contradictions in the accumulation strategies and the developmental hegemonic project, which culminated in its crisis.

This article, in addition to this introduction, is organized as follows. The second section highlights some elements and influences of the theoretical framework of spatial rescaling of the State proposed by Brenner (2004). The third section deals with "spatial developmentalism" and the configuration of a developmental spatio-temporal fix. The spatial regulation of developmentalism, focusing on the period after 1964 is discussed in the fourth section. Finally, the emphasis will be on the effort for regulatory improvement contained in the II PND (National Development Plan) and the consequent crisis of the developmental state.

\section{THEORETICAL BACKGROUND}

It can be said that the foundation for understanding the spatial rescaling of the State is the book New State Spaces, by Neil Brenner (2004). In this work, the author performs a sophisticated theoretical construction in which he critically and selectively brings together certain elements of 
State Theory, Anglo-Saxon Political Geography and Economic Geography (strongly influenced by the Regulation Approach) and International Political Economy to incorporate a theory of uneven spatial development into a State theory. Indeed, the author's contribution represented significant progress in building a spatial theory of the State, when suggesting concepts to analyze and understand the territorial and scalar policies involved in their complex spatial restructuring.

In view of the incorporation of the "scalar turn" in studies on the power of the State, Brenner "developed a sophisticated theory that anchors versions of New Regionalism over the production of new political and economic spaces to an understanding of the spatial restructuring of the State under globalization" in which contemporary forms of state space are "closely related to struggles over forms of accumulation and regulation in post-Fordism" (OOSTERLYNCK, 2010, p. 1156). Thus, in addition to theoretical issues (which are the concrete spatial forms of State power and how they evolve), the author presents new methodological issues (categories to explain the spatial restructuring of the State), periodization and contextual variation (comparative); and conjunctural analysis, related to how the inherited formations are being reconstructed (BRENNER, 2010a). The framework of the "new State spaces" also involves the mobilization of a conceptual vocabulary to analyze the political strategies for the rescaling of the State and the ways in which they operate through the State and reproduce and transform their institutional design (OOSTERLYNCK 2010).

The literature on State rescaling has been expanding rapidly in various fields of state policy, such as public administration and policy analysis. Issues such as intergovernmental relations, federalism, decentralization, localism, collective agency and sector specific policies have been increasingly analyzed in this light, which has been featured in special editions of prestigious journals (BRENNER, 2010a; BRANDÃO, 2011; KLINK and DENALDI, 2014; ANTIPODE, 2010; CAMBRIDGE JOURNAL OF REGIONS, ECONOMY AND SOCIETY, 2009). The framework of the State's spatial rescaling is also an important reference in an influential approach to the processes of neoliberalization (BRENNER, PECK and THEODORE, 2010).

Recently, this framework has been used in an increasing number of contexts and countries; it is important to test and adapt it to the Brazilian reality, in order to work critically with the concepts presented and improve its comparative potential.

This procedural methodology studies the spatial restructuring of the State based on territorial and scalar policies, so that it does not focus on any specific spatial scale of the State. Thus, while Brenner mainly highlights the urbanization processes (understood as a systemic regulatory problem of capitalism), its framework applies equally well to the regional scale (OOSTERLYNCK, 2010). As such, the approach proposed and adopted in this paper is concerned more generally with uneven spatial development processes under capitalism. The urban question, understood in this way, is a "scalar question". Thus, we consider that "the problem of geographical scale - its spatial organization, social production, political contestation, and its historical reconfiguration - was inserted into the heart of the urban question" (BRENNER, 2010b, p.69). This new concept has emerged as a result of discussions on globalization and the recognition of crucial changes "in the institutional organization not only of the urban scale, but also broader and global scalar hierarchies and inter-scalar networks in which cities are embedded" (BRENNER, 2010b, p.67). Although this framework was developed during the debates on globalization, its analytical categories were applied to understand the inherited institutional space of the State, including: i) the historically specific regulatory landscapes in a national territory; ii) the historically specific patterns of crisis formation, uneven development and socio-political contestation that emerged in these territories due to the crisis of the Fordist-Keynesian mode of development; iii) the interaction of neoliberal initiatives with the regulatory framework, existing spatial patterns and socio-political contestation, which often take on a path dependent character (BRENNER and THEODORE, 2002, p.357).

Thus, it becomes important to understand the occurrence and manifestations of these phenomena, as well as the scalar structure and its historical malleability in the spatial organization adopted by the form of the Developmental State. Developmentalism as a hegemonic project did 
not produce a stable configuration, but instead a dynamic and disputed form of spatial change (see SWYNGEDOUW, 2004).

Surprisingly, the State often takes a secondary analytical role in the theories of uneven spatial development (COX, 2008). This does not imply that the State (usually on a national scale) is not studied as an entity with different powers within a global hierarchical structure, or as a producer of inequalities through its policies. However, few authors have actually managed to integrate the State into the necessary transition from a law on uneven development to a theory of uneven development, in which the production of spatial scales takes on an explanatory role in the deterritorialization / reterritorialization of capital and State power amid simultaneous processes of equalization and differentiation of the conditions of production. Indeed, it is necessary to recognize that "the general form of the State is scalar and spatially articulated from the beginning" (COLLINGE 1998, p.6) and then analyze the processes causing changes in their form. The contribution of Brenner (2004), whose influences, concepts and effort of constructive synthesis are outlined in Figure 1, aims to overcome this gap.
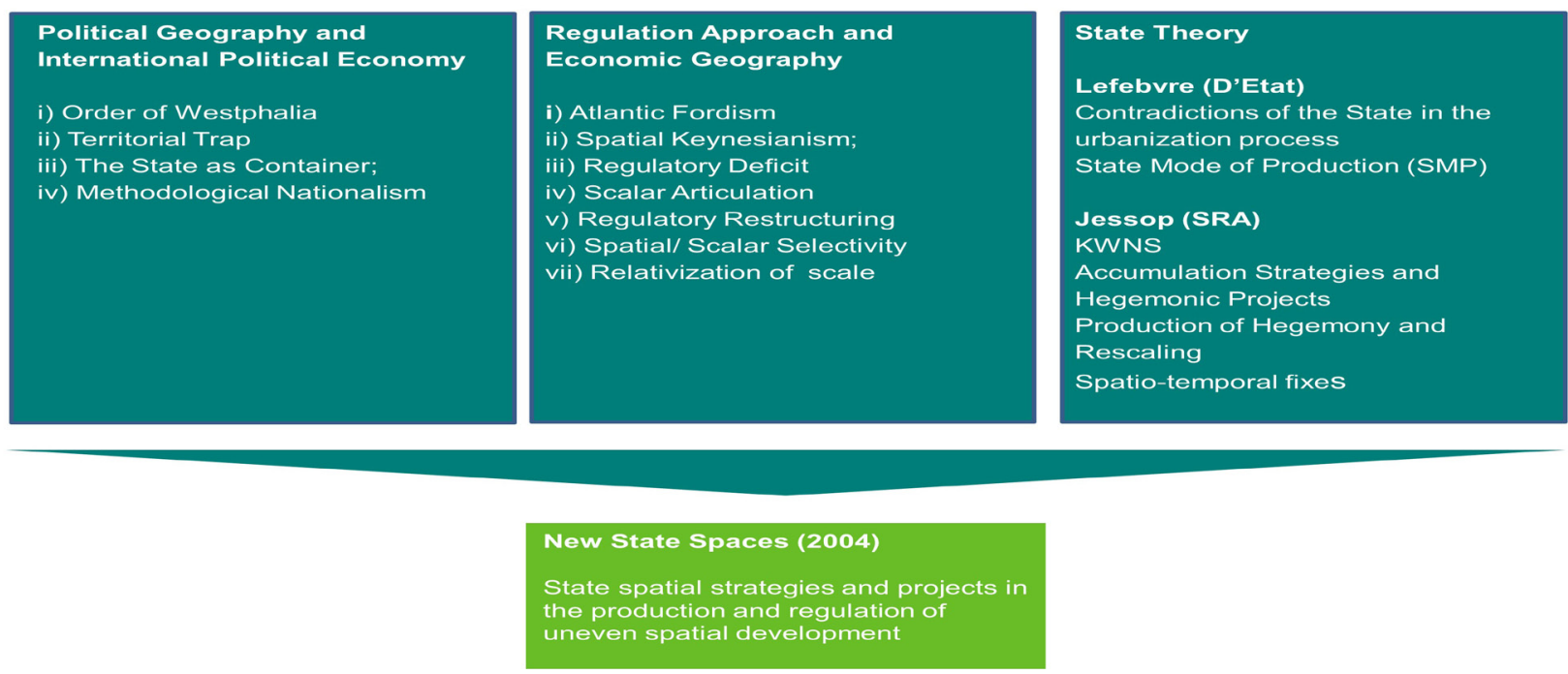

Figure 1 - Background and Theoretical Influences

First, based on contributions from Political Geography and International Political Economy, there is the idea that the spatiality of the State is not fixed, which is not limited to its scalar organization. It is important to avoid methodological nationalism and the limitation of a rigid spatial imaginary, which makes recognition of emerging spatial forms more difficult. Methodological nationalism cannot be overcome by only considering the relations between countries in a geopolitical scenario. It is also necessary to observe the changes in scales, in the State territoriality and in the emergence of networks, which provide crucial information about the national scale. In this sense, the debate on spatial scales and new processes of de/reterritorialization has much to contribute in discussions on globalization and the regulatory crisis of the Nation State.

The influence of British geographers (the "third generation" of regulationists) provided important elements for understanding the production of scales and their relation to uneven development. From the discussion of local modes of regulation, and the overlapping scales of the institutional forms of the modes of regulation it was possible to advance the view that there is no "ideal" scale and that regulation extends to various socio-spatial dimensions, such as inter-scalar, territorial arrangements and places and networks. It is important to mention these authors' fruitful dialogue with the Strategic-Relational Approach (SRA) of the State, developed by Bob Jessop. Another 
possible but less obvious dialogue lies in the similarity between the concept of regulation used and the idea of the reproduction of the social relations of production, developed by Lefebvre (1973). Both reject the emphasis on coherence, dominant in Althusserian structuralism, and are dedicated to understanding the conditions of permanence, repetition and production in social relations, in which the State and space play a crucial role.

In this respect, it is necessary to avoid a common reading of regulation, which exaggerates the coherence of the regime of accumulation and emphasizes the transition of regimes of accumulation, especially in a mistaken interpretation of post-Fordism. The temporality of regulation should focus specifically on change and not on binary comparisons between past situations and possible successors (GONZALEZ, 2004). In other words, "it is much better to study the existing forms of regulation that are positioning themselves than to think about their coherence" (LIPIETZ, 1993 apud GONZALEZ, 2004). Finally, the Eurocentric nature of interpretations of Fordism and its crisis, over spatial Keynesianism and the centrality of the Westphalia Order should be noted (BECKER, 1999). Hence the need for (re)working these concepts in the light of what the author has entitled spatial developmentalism. Indeed, some important aspects of change in institutional and organizational forms of the State regarding economic intervention and hegemonic struggles on different scales were developed by Oliveira (1981b) when explaining state intervention in the Brazilian regional question. These contributions, complemented by considerations of changes in regimes and scales of accumulation and regulation, in the accumulation strategies, territorial and scalar selectivities and changes in the degree of hegemony provide key elements for understanding the spatial rescaling of the State in the populist period (BARCELLOS DE SOUZA, 2012). Our intention is to examine some of these mediating concepts to understand the rescaling process during the military-developmentalism. The interpretation adopted intends to take advantage of the possibility of greater historical detail, also incorporating the strategies of hegemonic maintenance within civil society that end up disappearing in Brenner's (2004) analysis of the Atlantic Fordism of Western Europe (OOSTERLYNCK, 2010).

\section{SPATIAL DEVELOPMENTALISM AND SPATIO-TEMPORAL FIX}

To understand spatial developmentalism it is necessary to discuss what form of State produced this regulatory regime. First, one must accept that the theories of the developmental State (including ECLAC's) are typically state-centered, which is problematic for the understanding of its spatiality (BARCELLOS DE SOUZA, 2012). Although we emphasize the relative diversity of approaches to the State in Brazil, we argue that the approach of the United Nations Economic Commission for Latin America and the Caribbean (ECLAC) had a dominant position in the characterization of developmentalism. ECLAC's noteworthy key ideas on developmentalism are: "i) the framework lies in the relationship between center and periphery; ii) the inward-looking development strategy; iii) the role of technology; iv) Import substitution industrialization; v) the active role of the State "(IGLESIAS, 2010, p.48).

One of the typical limitations of developmental approaches is their sometimes exaggerated emphasis on the autonomy of the bureaucracy and the State's capacity to the detriment of the balance of social and political forces. There is an insistence that internal coherence, corporate identity and a coherent organization are key elements of Developmental States (JESSOP and SUM, 2006, p.155). In this sense, Jessop's strategic-relational approach to the State has more affinity with the interpretations of Poulantzas and Gramsci than with Weber's, enabling a closer dialogue with authors such as Oliveira (1981), Fiori (1995) and Cardoso (1993). Initially, it should be noted that the distinction is needed between policy paradigms and theoretical paradigms. Thus, even sophisticated interpretations of underdevelopment and developmental policies, such as ECLAC's, run the risk of being "absorbed" (or misinterpreted) by policy paradigms that have "their own mythologies used to justify 
and guide specific economic strategies and policies "(JESSOP and SUM, 2006). Nevertheless, in both examples there is a preference for State-centered approaches rather than a relational approach.

Using an ideal-type construction inspired by Jessop (2005), it is possible to analyze the four types of intervention (economic, social, scalar and governance) adopted by the State to ensure economic growth. From stylized versions of these types of intervention and the State's role in the developmental mode of regulation and regime of accumulation, we intend to advance in the spatio-temporal determinants of this form of State. Unlike the KWNS (Keynesian Welfare National State) of the Atlantic Fordism, and the LWNS (Listian Workfare National State) of the East Asia, the Brazilian State took on the form of a ECLAC welfare National State (ENw C)

Regarding the promotion of conditions for profitable accumulation, the State follows ECLAC, by relying on the national business community to advance Import Substitution Industrialization (ISI) and giving special attention to planning, centralization and economic nationalism in an inward oriented growth model. In this context, the State Productive Sector was instrumental in the allocation of investments and the regulation of profit margins. Development policies have undergone various theoretical influences in addition to ECLAC's theories, such as List's protectionism, Keynesian interventions in effective demand and Hirschmann, Myrdal and Perroux's concern with unbalanced growth,; the latter is a key reference in the 1970s due to his theories on growth poles. Despite these considerations, ECLAC's intellectual and political importance means it can be classified as the main theoretical reference in the construction of the Developmental State regarding its economic orientation.

Concerning the reproduction of the workforce as a fictitious commodity, it can be said that the Developmental State has taken on a welfare orientation. However, this element needs to be analyzed carefully, because this was not the case of a Welfare State which made a commitment to full employment and the guarantee of basic social rights to all people as a social policy and the maintenance of effective demand. Neither did the wage relationship systematically incorporate productivity gains in increases in the remuneration of workers in general, as the result of trade unions' broad freedom of negotiation and the establishment of a corporatist tripartite model. However, the Welfare category must be analyzed beyond its purely normative and positive aspects and understood as a capitalist form of the State in social and political regulation of its relations with the market and society (DRAIBE, 1993). Thus, it can be argued that Brazilian social security developed according to some of the general characteristics of the forms of intervention of capitalist States, but with a limited redistributive nature and within a fragmented institutional structure and meritocratic-particularistic (corporatist / clientelistic) type of Welfare State (DRAIBE, 1993). It is possible to point to the complementary nature of social policies to the Import Substitution Industrialization strategy and inward oriented growth, which depended on the consolidation of a middle class with sufficient purchasing power and high rates of urbanization and rural migration.

Thus, we can characterize the Brazilian model of developmentalism as an incomplete "welfare", which exercised some regulatory power on aggregate demand, but never craved to function as the redistribution mechanism of the product. The incompleteness is also manifest in the absence of minimum institutionalized income guarantees, a defining feature of developed Welfare States. On the other hand, Brazilian welfare distances itself from the workfare practiced in developmental States in East Asia. In the latter, the export model as a mode of development demanded high investments in human capital, an open economy that depended more on the flexibility of the supply than the domestic demand and a complex division of labor between various production sites, setting up a kind of "imitative flexible production " in which the pressure on wages stemmed international demand (JESSOP and SUM, 2006).

The ENwC is national to the extent that "economic and social policies were pursued within the historically specific (and socially constructed) matrix of a national economy, a national state and an imagined national community" (JESSOP, 2005, p.27). The scalar matrix of this spatio-temporal 
setting has its dominance on the national scale, which takes on the main responsibility in terms of economic and social policy. Discourse such as economic nationalism, National Security and the idea of "Brazil as great Power" were employed at different times to sustain the dominance of national territorial scale.

Finally, the ENwC is state-controlled as it fell to the State through planning, coordination, fiscal centralization and public investment to "discipline" the market, control (or protect) the trade unions and civil society and promote regional and urban development integration policies. Top down State intervention was the main governance mechanism used for capital accumulation, reproduction of the workforce and public policy. The growing "statism" was one of the trends towards crisis of this kind of State.

Following the advice of Jessop (2005) and Jessop and Sum (2006), we will adopt a regulationist perspective to better specify the ENwC. In actual fact, the spatio-temporal fix facilitates the consolidation of institutionalized commitment upon which the regime of accumulation and mode of regulation depend.

The continental size of Brazil and the enormous effort to build an inward growth model imply specific forms of displacement / adjustments. The developmental spatio-temporal fix contained various forward escape and damping mechanisms, in order to maintain its structured coherence and to delay its replacement by another fix. Among these, we can highlight inflationary financing, the occupation of the agricultural and mineral frontier, migration, regionalism, shifting cultivation, the "bloated tertiary sector" and selective social mobility. The establishment of a spatio-temporal fix administered on a national scale does not imply the absence of tension in search of impositions of other fixes in other scales. A spatio-temporal fix is understood as the establishment of some territorial and temporal boundaries that allow the reproduction of a "structured coherence" picking winners and losers in and out of a given economic space, associated with their specific (though disputed) standards of unequal distribution of benefits and uneven spatial development (JESSOP, 2008). In this sense, a spatio-temporal fix presupposes a spatial selectivity of the State related to an accumulation strategy. The developmental spatio-temporal fix needed to regulate tensions between internationalization and the construction of a national territorial receptacle, between the regionalists (who tried to impose their own settings) and the central power, the ambiguity of municipalism and the local scale in the grammar of Brazilian politics and the efforts of compartmentalization of the territory undertaken by different agents. These conflicts and tensions will be important in the institutionalization of spatial scales and the construction of competing scalar narratives throughout developmentalism.

In the construction of ideal types as KWNS, the LWNS or ENwC, the focus of the analysis lies in its structural aspects. The evolution of SRA (Strategic Relational Approach) helps to point out the contradictions, strategic dilemmas and critical junctures of these forms of State. Exploring the dialectic between the State's projects and spatial strategies in this light illustrates the social struggles and spatial, scalar and strategic selectivities in question. In this sense, we chose some situations that represent these selectivities and their changes, which partly reflect changes in the power bloc and the territorial and scalar organization of the state. The starting point is to treat the State not as a subject (that acts or should act in a certain way) or an object (used by classes, parties or bureaucracy to advance its interests), but as a social relation and, therefore, a project in progress rather than a finished structure. In the words of Jessop (2008, p.3), "it changes shape and appearance with the activities it undertakes, the scale on which it operates, the political forces acting towards it, the circumstances in which it and they act and so forth." The conception of the State as a "place that generates and produces strategies" incorporates these relationships.

Table 1 summarizes what Neil Brenner (2004) defined as the State's spatial strategies and spatial projects. Initially, it should be noted that ECLAC's ideas assumed that productive integration would cause some degree of spatial equalization: 
first, as a guarantee of stability of the national space on political, economic and social levels - a vital aspect for the ruling classes and the equal weight between regions -; second, because it was believed - thanks to ECLAC's ideas - that productive integration and the expansion of capitalist relations in industry and agriculture, resulting in increased productivity and regional income, would lead to greater regional balance (RODRIGUEZ, 1994 p.340-1).

However, the equalizing strategy was short-lived, proportional to the failure of the Superintendency for the Development of the Northeast (SUDENE) to achieve its industrialization, colonization and land reform goals.

Table 1 - State Spatial Projects and Strategies

\begin{tabular}{|c|c|}
\hline State Spatial Projects & State Spatial Strategies \\
\hline $\begin{array}{c}\text { Emerge as attempts to differentiate or integrate State institu- } \\
\text { tions and policy regimes across geographical scales and among } \\
\text { different locations within the state's territory }\end{array}$ & $\begin{array}{c}\text { Emerge as attempts to mold the geography of industrial development, } \\
\text { infrastructure investment and political struggles into a "spatial fix" or } \\
\text { "structured coherence" }\end{array}$ \\
\hline $\begin{array}{c}\text { Target: spatially differentiated state structures } \\
\text { Possible outcomes: consolidation of spatial and scalar divi- } \\
\text { sions of regulation }\end{array}$ & $\begin{array}{c}\text { Target: the geographies of accumulation and regulation within a State } \\
\text { territory }\end{array}$ \\
\hline Uneven development of regulation & $\begin{array}{c}\text { Possible outcomes: spatially selective accumulation strategies and / or } \\
\text { hegemonic projects }\end{array}$ \\
\hline
\end{tabular}

Source: Brenner (2004, p.91)

\section{SPATIAL REGULATION DURING THE MILITARY PERIOD}

The regional policy of the postwar period was marked by adaptation to the ISI accumulation strategy. Regarding the State's spatial strategies, the national-developmental phase of regional policies was characterized by the combination of a spatial concentration strategy (in the Southeast, due to the "Plano de Metas") with an equalizing spatial strategy, mainly represented by the creation of SUDENE in 1959. This resulted in a double spatial selectivity, in São Paulo, where most investments were focused and the Northeast, where the first major regional planning experience was carried out.

The coexistence of a concentrating spatial strategy partially offset by an equalizing strategy ended with the reconfiguration of the state apparatus due to the transition in the power bloc and the accumulation regime. From the configuration of a "two nations hegemonic project" and "wild" peripheral Fordism, a new spatial strategy based on national integration would coexist with a strategy of concentrated accumulation and a new regulatory layer that would be superimposed on the State apparatus and the previous projects and strategies (BARCELLOS DE SOUZA 2012). The conditions of this coexistence changed over time, as illustrated by the development plans and changes in the territorial and scalar selectivity of the policies. However, although it is possible to state that the national integration strategy aspired to a spatial deconcentration arising from the occupation of the territory, most of the time there was a clear subordination of this strategy to the project of efficiency, depending on the spatial concentration of human and capital resources for the continuation of ISI. Despite this "subordination" it would be a mistake to fall into economism. It is important to highlight the conflicts that crossed the state as new interests and actors emerged and tried to direct state spatial projects and strategies in a territorial and scalar manner. These conflicts suggest more nuances and prevent the characterization of a mere concentrated spatial policy on the period.

With respect to state spatial projects, it is necessary to bear in mind the processes of financial and administrative centralization that started after 1964 aiming to adjust them to the national accumulation strategy. In the first case, there was the effect of the 1966 Fiscal Reform and its relationship with the restructuring of the State. At that time, the centralization of resources and power 
in the Union occurred by: i) transferring some taxes to their competence; ii) linking the transfer of resources from the State and Municipalities Participation Funds, subordinating them to the decisions of the Federal Government and making them compatible with the requirements of accumulation; and iv) the federal decision on the rates of VAT (OLIVEIRA, 1981).

Regarding administrative centralization, between 1967 and 1974 there was the expansion of the regional presence of the central administrative apparatus and its decentralized agencies (foundations, autarchies, and state enterprises). The state government's reproduction of the federal administrative structure allowed the central government to mold this structure, since the states believed that the model would facilitate the transfer of funds. In fact, it facilitated agreements between states and the Federal Government by setting a precarious form of intergovernmental coordination, in which the Union drew up the policies and it was up to the states to abide by them (SALLUM JR, 1996).

The administrative centralization was marked by the military government on the grounds of better coordination of economic policy and the State apparatus, which had repercussions on the assembly of "super-bodies" in charge of integrating smaller agencies and policies. This procedure was also adopted for the coordination of territorial policies. While still responsible for the administration of tax incentives and regional investment funds and co-opting regional elites, the regional superintendencies lost prestige and importance.

That said, it is useful to remember that the institutional framework of SUDENE as a State spatial project was set up with a view to a spatial selectivity based on a regional ISI accumulation strategy and the containment of popular counter hegemonic struggles. After the 1964 coup the type of spatial selectivity for the Northeast Region lost importance and took on a dimension more related to facilitate the expansion of capitalism in the dynamic Southeast and the subordination of local regionalism.

A new form of spatial selectivity in the national-regional axis, fomented mainly within the hegemonic segment in control of the State apparatus - it had been a longstanding goal of the Armed Forces, strengthening the role of the State as a generator of strategies - gained momentum during the preparation of the National Integration Plan (PIN), launched in 1967. In this case, national integration became relevant as spatial strategy of the ENwC, its goal being the expansion of the country's economic frontier. The concept of frontier took on different meanings and would legitimize different policies, including the Northeast, North and Center-West regions. Despite the Northeast being included in the PIN objectives, its execution favored the Amazon and, secondly, the Center-West.

In the case of Amazon, military policies for the region had a different quality from those resulting from the construction of Brasilia and the "Highway axes". This was a result of changes in the model of development and in the power bloc, which covered the national security doctrine with a geopolitical bias. Among the main policies for the region in the late 1960s were: i) the creation of SUDAM (Superintendency of Development for the Amazon) and use of the same tax incentives applied in the Northeast in 1968; ii) the creation of SUFRAMA (an exception among the macro-regional Superintendencies), reinvigorating the role of the Manaus Free Trade Zone in 1967; iii) the geopolitical content expressed in the goal of colonization and settlement; and iv) an "official" program of colonization, supporting the settlement of small farmers (usually Northeastern) in the areas around the highways.

In addition to these official goals, spatial policies in the North had another type of objective. First, the infrastructure projects and the occupation of the territory freed up a vast area of land that was used as an investment by the capital of the Centre-South due to its almost zero price and huge future value. Moreover, the process of land reform implemented complied with the goal of settling the colonizers on public land, but keeping land ownership untouched in the rest of the country (NABUCO, 2007). As highlighted by Maria Regina Nabuco (2007), in the mid-1970s the relative importance (or spatial selectivity) of the Amazon in the government's regional development plans was reduced. Among the reasons for this, the author points to the low agricultural productivity, the 
"closing" of the best land by the capitalists of the Center-South and the increase in transport costs for merchant consumers due to high oil prices.

In response to this "hollowing out", some measures would be launched by the II NPD (National Development Plan). Before discussing them, it is worth highlighting the prominence of the Center-West Region in the spatial strategy of national integration, at the same time that planning in the Amazon lost its initial importance. At that time, the concern about the economic frontier represented a shift toward the adoption of programs to expand agricultural and agro-industrial modernization. The Center-West played a prominent role in this strategy, as there was an ample availability of fertile and cheap land, in a context of rising international prices of food and raw materials (NABUCO, 2007).

Established in 1967, SUDECO`s (Superintendence of Development of the Center-West) priorities included: i) the integration of new land for agricultural production; ii) planned migration, in order to fix populations when promoting rural-urban integration; and (iii) a productive relationship with foreign markets, through the export corridor based on the technological development of agriculture and industrialization of production (GUIMARÃES NETO, 2010). Indeed, the II PND was the institutional rule that allowed the incorporation of the frontier of the Brazilian Center-West, setting as one of its goals improved integration between the regions and closer relations between urban and rural areas, supported by agro-industrial modernization (NABUCO, 2007, p. 75). In other regions, the plan also implied a more aggressive occupation of the frontiers, with the implementation of rural "growth poles". In this way, there was a proliferation of agro-industrial and agro-mineral type programs, such as POLAMAZONIA, POLOCENTRO and POLONORDESTE, which reinforced land concentration and were not intended to deal with regional problems (BERCOVICI, 2003).

The II PND was a rescaling of regional policy and the reaffirmation of the State in the territory, replacing the macro-regional level of superintendencies by the scale of operation of the growth poles (and their regional, national and international irradiation). This new scalar selectivity was defined by the fact that regional development would be done by the articulation between the state and domestic and foreign big capital, crystallized in Large Investment Projects. The policy based on poles represented a "shortcut" that bypassed the scale for which the regional superintendencies were designed, highlighting their incoherence in view of the "hollowing out" of the regions.

The State's spatial rescaling strategy, embodied in the growth poles, represented a change in "the modes of scalar / global connection" (JESSOP and SUM, 2006), in keeping with dependent capitalism and the productive and financial internationalization. The handling of the internal and external flows of the poles was not always successful, producing other uneven development patterns mediated by the State on various scales and the resulting difficulty of spatial "filtration" and local retention of the generated surplus. Accordingly, the following were verified: few effects of attraction; the use of unskilled labor (or non-use of local labor) and disorderly migration flows ; the allocation of resources to privileged locations, increasing the dependence on technology and research in relation to other regions and countries; the risk of creating "poles within poles", increasing inequalities in backward regions; the risk of enclaves; increased industrial concentration instead of diffusion; and application in agricultural activities that favored local political leaders (BOMFIM, 2007).

The ENwC's spatial projects that interacted with strategies and spatial selectivities under analysis were not limited to financial and administrative centralization and the configuration of the Superintendencies entrusted with the implementation of regional policies. The production of internal borders played a key role in the spatial regulation and the policy of developmentalism. Relations between the central government and the regional oligarchies in Brazil have always been marked by many tensions, which resulted in the need to accommodate competing interests. The redefinition of internal borders is an important element in the Brazilian context, which was used several times by the State as a technology of power (MARTINS, 2001). In the developmental period several territories have been created and afterwards some were elevated to the category of States of 
the Federation. Thus, there was the creation of Acre (1962), Mato Grosso do Sul (1979), Rondônia (1981) and the merger of Rio de Janeiro (1975). This creation of States was part of the project of "political engineering" of the federal government in order to "manufacture" majorities in Congress through the manipulation of electoral rules.

The Constitution of 1946 granted greater autonomy to municipalities, giving them freedom in setting taxes and a larger share of the transfer of federal and state resources, which resulted in the multiplication of municipalities and a new territorial pact that would last until the military coup in 1964. Cataia (2006) illustrates how the creation of municipalities in this period amounted to spatial projects of the State that followed the spontaneous colonization, which aimed to extend the State's presence to areas that did not have the help of the state government and were distant from the municipal seats.

The military government's spatial strategy of national integration supported itself on the creation of municipalities as a spatial project of the State and as a principle of the rational organization of territory that was only possible through the centralization of power. There were several federal intervention devices mechanisms for municipalities, including the linkage of the revenue of the newly created Participation Fund of the Municipalities, the jurisdiction over the creation of new municipalities (which previously belonged to the States), the appointment of municipal mayors in areas of national security by the President and the appointment of mayors of capital cities by state governors.

During the period 1964-1967, the creation of municipalities was concentrated in the Center-South, which is consistent with the division of labor led by a concentrating spatial strategy. However, between the late 1960s and the late 1970s, the creation of new municipalities shifted to the Center-West, illustrating "the use the central government made of the municipal borders as one of the integrating elements of the Center-West region to the national and international economy "(CATAIA, 2006). In this sense, the military's spatial strategy of national integration and agricultural modernization demanded the expansion and modernization of transport and communications systems, allowing not only the economic development of those areas, but also the expansion of the political fabric, facilitating the diffusion of orders by the central government.

The spatial integration strategy through agricultural modernization was accompanied by the spatial project that involved the creation of new municipalities to regulate social, economic and political conflicts. The concentration of new municipalities in the Center-West from the late 1960s, given the role that municipalities took on in the scalar division of regulation implies a differentiated concern of the State in the regulation of local conflicts and the establishment of new spatial division of regulation to allow their greater presence and political and economic control in the area.

With respect to State spatial projects in the period 1964-74, it is worth mentioning the institutionalization of Metropolitan Regions (MRs) in 1973. At that time, nine metropolitan areas were officially created around the cities of São Paulo, Rio de Janeiro, Belém, Fortaleza, Recife, Salvador, Belo Horizonte, Porto Alegre and Curitiba. According to Souza (2003), the MRs were created in response to the rapid urbanization of the 1970s and met the objectives of centralization and control of the most dynamic areas by the military regime. The model adopted, despite being based on clear legal-political-territorial demarcations by the central government did not create incentives for cooperation between the State and the municipalities or between the municipalities of a MR. Neither did it generate a regional identity around the MRs, given the lack of interest of the citizens, the lack of political participation and the wide disparities between MRs.

That said, the 11 PND represented not only an attempt to reset the mode of regulation to the dynamic crisis of the regime of accumulation. It was also an effort to resolve contradictions caused by uneven spatial development, promoting a new relationship between State spatial projects and strategies. This is because the pattern of "forward escapes" that helped sustain the developmental 
spatio-temporal fix eventually came up against structural limits. As will be seen below, the circumstances that led to the implementation of the Plan were one of these limits. However, attempts to recalibrate engendered even more complex contradictions, whose evolution culminated in the crisis of the Developmental State. Some of the uneven development patterns are given below:

The concrete fragility of the growth poles as spatial-economic policy

- The year 1970 represented the peak of industrial concentration in São Paulo, especially in the most dynamic sectors (capital goods and durable consumer goods) from the installation of heavy industry with the Target Plan (Plano de Metas, 1956-1960), and its regional linkage effects (CANO, 1998).

- Rapid urbanization in the period was the result of strong population growth between 1950 and 1960, the accelerated industrial development and the migratory waves, especially to the two major cities in the Southeast (São Paulo and Rio de Janeiro). In the 1970s, the average annual increase of the urban population was already higher than that of the total population and in this context metropolization became important. Until 1960, only the cities of São Paulo and Rio de Janeiro had more than one million inhabitants and could be considered metropolises. However, the growth of large cities occurred in all regions of the country throughout the 1970s, especially in the cities ranging between 250,000 and 500,000 inhabitants and between 500,000 and 2 million inhabitants (SOUZA, 2004). Between 1950 and 1980, the share of the current metropolitan areas in the total population jumped from $17.95 \%$ to $28.93 \%$. In that context, industrial decentralization programs, the internalization of development and the incentive to medium-sized cities gained importance.

- The town planning legislation did not adapt to the demographic, economic and social changes in the period, focused more on the regulation of the opportunities for capital gains in real estate - settled in spatial segregation - than the social regulation of the city and the necessary provision urban of infrastructure and housing for all (QUINTO JR, 2003).

- The "Oblivion of the Federation" (SALLUM Jr, 1996) caused by the Fiscal Reform of 19661967 and the promulgation of Institutional Acts by the Executive caused tensions between levels of government, politicians, segments of the State apparatus and civil society. Centralization, as we have seen, arises not only as an economic necessity but also a political necessity of the hegemonic bloc. After the coup the new federation facilitated the execution of federal public policy through the establishment of agreements and the conditioning of transfers of Participation Funds to meet measures such as minimums on capital spending in municipalities. Furthermore, it established a special kind of relationship with the state governments, their state-owned enterprises and state banks. According to Lopreato (2000, p.118), "Access to the credit market [via federal credit agencies or foreign loans] allowed the States to divest themselves of existing fiscal ties and to surpass the problems created by the concentration of power to impose taxes at the federal level. "Regarding the political aspects, as well as the subordination of state governments there was an attempt to homogenize the regional elites by the Médici government, because, given the regime's selection rules the space for fighting was restricted to the arena of the State (SALLUM JR 1996 ).

The analysis of projects and spatial strategies in the period 1964-73 illustrates the apparent contradiction between spatial strategies that had urban support, geared toward the ISI or toward the internalization of development, and "anti-urban" spatial projects. A strategic-relational observation of II PND, with its complex environment and lasting repercussions on the developmental crisis, may help explain the unfolding of this contradiction. 
The II PND failed to unify the different moments of the circuit of capital accumulation according to its strategy, aimed at the renewal of the ISI strategy and development of the segments of intermediate goods and capital goods. The strategy was based on giving economic hegemony to the state's productive capital, which involved the general acceptance of this position, especially by the national private productive capital and the national financial capital (LESSA, 1998). In practice, construction (linked to financial capital) and the great national engineering exercised economic domination, that is, through the control of extra-economic forms with privileged access to the state, had the ability to impose their economic and corporate interests over other fractions of capital. However, economic dominance was unable to ensure the integration of the circuit of capital and sustain accumulation in the long run, given the negative effects imposed on industrial capital. In other words, it would be necessary to destroy a network of commitments based on specific economic interests that supported the former ISI strategy and build a new network of commitments "to expedite the cash transfers necessary to implement the capital goods industry and heavy inputs" (DIAS and AGUIRRE, 1993, p. 311).

The approach must be increased by conflicts within the state apparatus, which can be understood in the light of the hegemonic project and manifest themselves in the political costs of bipartisanism , the deconcentration of power between state agencies, the intervention by appointing governors and conflicts within the Armed Forces.

The attempt to promote a fit between the new accumulation strategy and the continuation of the developmental hegemonic project depended on the regime's ability of "institutionalization". It can be argued that this would be the key step in making the transition from a "two nations hegemonic project" to the kind of Passive Revolution that the military initially longed for. The conflicts present in the attempt to reconcile the hegemonic project with the accumulation strategy sought a spatial adjustment through the State's spatial projects and strategies.

In addition to avoiding any analytical privilege between the political or the economic, when favoring the dialectics between both, the SRA provides a better understanding of the different strategies in circulation and their selection and retention through the State. According to Aguirre and Saddi (1997), it is possible for the Developmental State to take a double domination, through a rational-legal form and another neopatrimonialist one based on the alliance with backward elites, which influences their forms of expansion. Thus, there was a need for new programs to capture new groups, in a disorderly expansion process, as the old guard resisted leaving the government and their permanence was agreed to through trading benefits. As Jessop argues (2008), what matters in neopatrimonialism as governamentality is how these forms of immanent power circulate in certain social relations. That is, how can they be colonized and reproduced in more general mechanisms that underlie wider forms of domination; and how they can be linked to specific objects of governance. Most importantly, however, is its articulation with concrete strategies of State power and class. These relationships will be gauged by the spatial strategies and projects of the State and the realignment of the federative pact.

These changes are expressed in the effort to revitalize the federation as a way to control the institutionalization process of the regime from 1974 to 1982 (SALLUM JR, 1996). The ruling party's election defeat was decisive in this sense because, from its fragmentation, the central government began to consider governors as strategic allies, reversing the centralization trend. Through productive deconcentration, General Geisel approached the governors and politically valued the regional elites by changing the electoral rules to favor the elites of the least developed and urbanized regions.

Changes in fiscal federalism accompanied the new political pact, particularly: i) the gradual recovery of the rates of the FPE and FPM (State and Municipal Participation Fund), to the original $20 \%$; ii) the elimination of the conditionality of FPE transfers and raising its volume for the North and Northeast; iii) an increase in the ICM (VAT) rate (with special treatment of the states of the North and Northeast); iv) the expansion of the cooperation agreements as a form of articulation between 
state and federal bureaucracies, prioritizing use of resources in the northern and northeastern states; v) changes in credit limits for states and municipalities; vi) facilitating access to foreign credit by state banks. As argued by Saddi (2003), federalism joined the political and electoral mechanisms as a political resource in promoting the government project, aiming to change the relationship with States and municipalities, the redirection of investment and the distribution of regional income.

The realignment of federalism during the Geisel government would take another direction with the April Package in 1977 and the adjustment of the major political forces in the decision to proceed with import substitution and "control" political liberalization (AGUIRRE and SADDI, 1997). Thus, the April Package promoted changes in electoral rules that increased the representation of backward spaces and those allied with the government. In this sense, the decentralization of the Geisel government can be seen as paradoxical as it opened a space for the States and municipalities to begin to criticize the fiscal system, which produced unexpected results. By transferring more power the Executive would come under pressure to transfer more resources and to mitigate the financial dependence of the States, and then "loses control in the political transition process" (SADDI, 2003, p.42).

The result was a "deadlock federalism" that decentralized resources but not the competence, which would have repercussions on the 1988 Constitution itself. In addition, the overrepresentation of the most backward states plus the governors' veto power would block the necessary fiscal and tax reforms (idem). As argued by Sallum Jr. it is necessary to speak of two distinct movements of decentralization in Brazil: the first was controlled (or top down) decentralization, between 1974 and 1982; and the second, started from the 1983/4 reforms and culminating in the 1988 Constitution, as a "grasped" (or bottom up) decentralization promoted by the advances of new centers of power in the interior of the State, propelled by the civil society and facilitated by the international context.

To end the discussion of state spatial strategies and projects during developmentalism, it is necessary to present a brief comment on urban policy in the period. The National Urban Development Policy (UNDP) emerged as a chapter of the II PND, although there were strong contradictions between them. In general, the problem was the clash between a sectorial "economic" view concerned with efficiency, and other "spatial" view of urban planning, aimed at devolution and territorial planning. The economic / sectoralist view was the winner, which served the hegemonic interests of the Center-South capitalists (especially investments in southern and southeastern Metropolitan Regions) and devalued the Program of Medium-Sized Cities. The proposed integration between territorial and urban planning gave preference, in the Plan, to the metropolitan areas, but in practice this did not occur given the aforementioned difficulties of intergovernmental coordination (Souza, 2004).

In short, the nature and objectives of the projects and spatial strategies during Military Developmentalism are shown in Tables 2 and 3. 
Table 2 - ENwC Spatial Strategies (or Spatial Developmentalism)

\begin{tabular}{|c|c|r|}
\hline \multicolumn{3}{|c|}{ General Lines: nationalization; concentration; homogenization-ecumenism; integration. } \\
\hline \multirow{3}{*}{ Spatial Selectivity } & Southeast & concentration: ISI (1955-1980) \\
\cline { 2 - 3 } & Northeast & equalization/stabilization (1959-1964); ISI (1974) \\
\cline { 2 - 3 } & North & national integration (1967); agricultural modernization and exportation (1974) \\
\cline { 2 - 3 } & Center-West & national integration; agricultural modernization and exportation (1974) \\
\hline Scalar Selectivity & Macro-regional & 1959-1974 \\
\cline { 2 - 3 } & Growth Poles & 1974 \\
\hline
\end{tabular}

- Brasilia (1960): promoted a framework for circulation in the national territory.

- Manaus Duty Free Zone (1957): Extra-territoriality. Subject to a special tariff scheme, it was created basically for the domestic market. It depends on the level of tariff protection in the domestic market. It concentrated the industrial activity of assembly of electronic and optical devices, physically distancing these segments from the metal-mechanical complex. Poor relationship with the productive structure of the region, so that its implementation acted more like an urban policy for Manaus than a development policy for the Amazon (EGLER 2010, BERCOVICI, 2003).

- Medium sized cities: To facilitate the "interiorization" of development. "Smooth" articulation with the hinterland and the urban network. Functions of relation and intermediation. Capacity to absorb and retain migrants. In practice, promoted a "deconcentrated concentration", favoring the great centers in the Center-South.

- Creation of new municipalities: "socio-political fabric". Result of the increase of the social division of labor, the need to alleviate urban/rural tensions and the power to compartmentalize the territory by dominant agents. From the end of the 1960s and 1970s, concentration of the municipalities in the Center-West, as part of the national strategy of integration and agricultural modernization.

- Constitutional Funds and Regional Investment Funds: In the former, the participation funds of the municipalities and states, whose rates were reduced after the Reform of 1966/7 and gradually recovered after 1974, when they were more directed to backwards regions. The later refers to the administration of regional fiscal incentive programs, carried out by the Regional Superintendencies.

- Horizontal mechanism of balance of the fiscal system, that transfers resources from more developed regions to less developed ones though participation funds. The fiscal system is highly interdependent, which means every time the economies of the rich states cool down the effects are soon felt by the poorer states.

- Rigid inter-governmental relationships: The conditionality of the inter-governmental transfers and agreements targeted the application in areas favored by the Union, notably the high participation of capital spending.

- State Owned Enterprises: Provision of town infrastructure needed for the industrial dynamic and urbanization (electricity, sanitation, housing and telecommunications). Provision of the generalized means of production in the production chain through federal holdings, as intermediary inputs. Acting mainly in the oil industry, mining and steelworks. Cements the articulation between national and international private capital (OLIVEIRA, 1990).

- Growth Poles: Widely accepted in Brazil, were also adopted as agricultural- mineral or agricultural poles.

\section{- Regional Development Banks}

- Land speculation: Always a strategy privileged by the State in its pacts with the territorialist and urban elites, enabling both a guaranteed accumulation reserve and the distribution of power in the hegemonic bloc.

- Occupation of the Economic Frontier: based on its agricultural, industrial, urban and settlement instances and through regional infrastructure.

Source: Own elaboration inspired by Brenner (2004) 


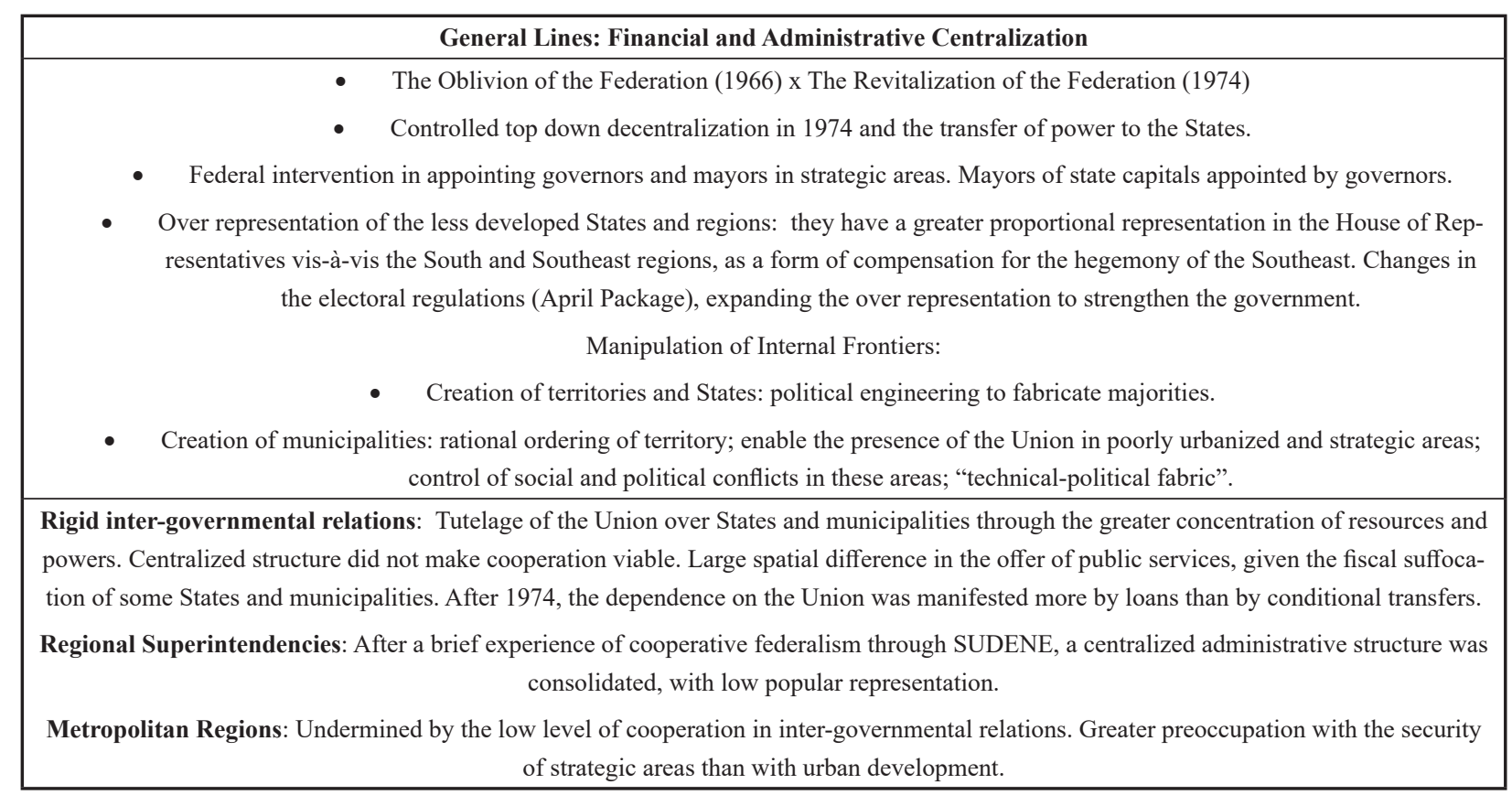

\section{FINAL CONSIDERATIONS}

Before highlighting the contradictions in the regulation of uneven development, it is necessary to briefly summarize the results of these spatial policies. Regarding the more general question of regional industrial deconcentration, it can be argued that the results were ambiguous, given the variety of strategies implemented and spatial selectivity that guided them, in addition to the decision to avoid transfer of capital and resources that would undermine the overall efficiency of the economy. So we agree with Bercovici (2003) regarding the clear non-intentionality or rather, the lack of priority of the State in the promotion of industrial decentralization policies. However, as Egler (1996) argues, by the end of the 1980s the country had specialized, differentiated and regionalized production structures with a reasonable degree of complementarity between them; revealing the inadequacy of analysis based on center-periphery relations. Although industry continued to be heavily concentrated in the Southeast, especially in the sectors of capital goods and consumer durables, for intermediate goods, especially the chemical industry, a less concentrated pattern was consolidated, with an emphasis on production in the Northeast. In addition, there was a reasonable production of durable consumer goods and capital goods in the North - due to the Manaus Free Trade Zone - and the establishment of a modern agro-industrial complex in the Center-West. Alongside the effects of these dynamic poles on the regionalized productive structures in which they operate, the emergence of powerful regional economic groups is apparent, which would come to have significant political influence on the direction of economic policies.

Despite these advances, some issues remained insoluble, while new problems arose. Regarding the Northeast for example, it should be noted that the type of industrialization was concentrating in terms of the scale of capital, since the tax incentives did not benefit small and medium capital. Moreover, the modernization achieved did not mean a change in the rules of sociability and more localized power structures, as verified by the strong influence of the agricultural sector on the 
employed population (OLIVEIRA, 1990). The industrial standard would continue to be governed by dependence and complementarity in relation to the industry in the Southeast (Bercovici, 2003).

Metropolization would be somewhat delayed, but in 1980 the urban concentration and its problems would be reproduced in the Northeast and North, exposing the failure of the UNDP. The development of an oppositional urban middle class in backward regions was crucially important in the struggle for democracy and the overthrow of authoritarian rule. On the other hand, the II PND's gamble on an alliance with non-capitalist oligarchies also took its toll: in addition to being more oriented by a substantive rationality, when State investments were delayed or reduced the regional elites joined their capitalist counterparts and increased the "isolation" of the State.

The limited modernization of the economies promoted by investments in infrastructure by the II PND had another problematic consequence: it served as a basis for those States to practice a fiscal war a few years later (ABRUCIO and COSTA, 1998). In addition, the industrial deconcentration based mainly in intensive segments in natural resources was a facilitator for these regions to seek a passive commodity-based integration after the commercial liberalization followed by the break in inter-regional productive chains.

What would become clearer, however, would be the tensions and the deleterious effects of "deadlocked federalism", as a result of the increased power acquired by the governors, especially after the 1982 elections. This was the beginning of the second wave of devolution, now bottom up in nature. However, deadlocked federalism was marked by high debt and worsening state finances and the establishment of relations that would bar fiscal and tax reforms until the "Plano Real" in 1994.

Based on the discussion above, we can state that the II PND was also an attempt to improve the spatial regulation mechanisms of developmentalism, which did not necessarily address the problem of production of uneven development. In fact, what happened was the recognition of the political costs of an authoritarian fiscal centralization and the need for the State to develop the rules of selection of new interests to avoid becoming "locked in" to certain trajectories, which resulted in expanding its condition as a "local" of strategies. Parallel to the establishment of these rules, the State exercised power through the search for coherence between its strategies and spatial projects. In some areas this coherence was achieved, as in the national integration via agricultural modernization of the Center-West and the policy of creating municipalities in the region; or the relationship between the revitalization of the Federation and the expansion of the rates of participation funds and the creation of Regional Investment Funds, such as FINOR. At other times, the coherence was only temporary, like increasing the representation of backward areas, with their conservative elites and a greater presence of modern state enterprises in these regions; or between "controlled" decentralization, with the end of conditionalities on transfers and the governors' loss of control over state finances.

In any case, in the same way in which it failed to recalibrate the mode of regulation to continue the ISI, the II PND also failed to promote a normalization of the spatial-temporal scope of regulation, that is, to provide a horizon of reasonably convergent and stable decisions for the agents. Moreover, even with a deconcentration proposal it was unable to eliminate the manifest uneven spatial development patterns and even deepened some of these trends.

As with the KNWS, the ENwC that arose during the post war period also supported new ways to organize, produce and transform the political and economic space. The "regulatory architecture" of spatial developmentalism was composed of various State projects and spatial strategies, whose scalar and territorial projections corresponded to the balance of forces in the hegemonic bloc and the forms of structural and strategic selectivity of the State. In general, there was a strong centralized political regulation of urban spaces through dependence of resources and transfers and "bilateral" negotiations that promoted a wide spatial differentiation in the provision of services. The ENwC also sustained itself on the extent of its control of sparsely populated and strategic areas by creating municipalities. Despite huge investments in infrastructure, the State's spatial strategies prioritized the search for essential agglomeration economies for the ISI model and the occupation / exploitation of 
territory vis-à-vis the equalization of industry and services distribution within it. This combination had impacts on the (re)production and sanctioning of built environments and characteristic land use patterns, marked by speculation, segregation, peripherization and informality.

The type of regime of nationalized inter-scalar rules covering the cities, regions and other subnational spaces consisted of transfers, loans, agreements, participation funds and regional investment funds, and helped to reinforce the dominance of national scale.

Nevertheless, amid the breakup of prior solidarities maintained through an accumulation strategy incapable of being durable; that is, through the conflicts that intensified and crossed the state apparatus threatening the developmental hegemonic project, new agents and relationships gained relevance. The period of crisis that loomed offered these agents strategic possibilities and different action horizons, making it difficult to specify the conditions for a new stabilization. Among these agents, we can highlight the governors, business elites and organized civil society, manifested in new unionism and the municipal movement.

The ENwC would suffer tensions in its four areas of intervention: the crisis in the ISI model, the pressures for consolidation of a complete Welfare and the decentralization of social policies, the emergence of subnational power centers and new models of bottom up governance, crossed by the proliferation of public policy networks. This was how the crisis of developmentalism, democratization, decentralization and neoliberalism converged on State restructuring, producing new rescaling processes. In effect, neoliberalization as a process of permanent and contradictory restructuring of pro-market governance has its origins in multiple spaces, scales and interconnected circuits. Thus, more important than pointing to a definite mark is to follow this process. That is, to track the historical geographies of neoliberalism from the developmental crisis.

\section{BIBLIOGRAPHIC REFERENCE}

ABRUCIO, Fernando e COSTA, Valeriano. Reforma do Estado e o Contexto Federativo Brasileiro. Série Pesquisas, n.12. Fundação Konrad Adenauer, 1998.

AGUIRRE, Basília; SADDI, Fabiana. Uma alternativa de interpretação do II PND. Revista de Economia Política, vol 17, n.4(680, 1997.

ANTIPODE. Volume 42, n. 5, pp 1151-1179, Novembro 2010.

ARANTES, Pedro Fiori. Em busca do urbano: marxistas e a cidade de São Paulo nos anos de 1970. Novos estud. - CEBRAP, São Paulo , n. 83, p. 103-127, Mar. 2009

BARCELLOS DE SOUZA, Marcos. Espacializando o desenvolvimentismo: imaginário, escalas e regulação. Revista Brasileira de Estudos Urbanos e Regionais, v. 14, n.2 / Nov, 2012.

BECKER, Bertha. Brasil-Tordesilhas, ano 2000. Revista Território. Rio de Janeiro. ano IV, n” 7. p. 7-23, jul./dez. 1999.

BERCOVICI, Gilberto. Desigualdades Regionais, Estado e Constituição. São Paulo: Editora Max Limonad, 2003.

BOMFIM, Paulo Roberto. A Ostentação estatística: um projeto geopolítico para o território nacional: Estado e planejamento no período pós 64. Tese (Doutorado em Geografia). Faculdade de Filosofia, Letras e Ciências Humanas da Universidade de São Paulo, São Paulo, 2007.

BRANDÃO, Carlos. Descentralização enquanto modo de ordenamento especial do poder e de reescalonamento territorial do estado: trajetórias e desafios para o Brasil. In. DALLABRIDA, Valdir. Governança territorial e desenvolvimento. Rio de Janeiro, Garamond, 2011

BRENNER, Neil. New State Spaces: Urban Governance and the Rescaling of Statehood. Oxford: Oxford University Press, 2004, 351p.

BRENNER, Neil. Restructuring, Rescaling, and the Urban Question. Critical Planning, Summer 2009a.

BRENNER, Neil. Open questions on state rescaling. Cambridge Journal of Regions, Economy and Society, Vol 2, n.1, pp.123-139, 2009b. 
BRENNER, Neil; THEODORE, Nik. Cities and the Geographies of "Actually Existing Neoliberalism". Antipode, 34, 2002, pp.349-379.

BRENNER, Neil; PECK, Jamie; THEODORE, Nik, 2010a. Variegated neoliberalization: geographies, modalities, pathways. Global Networks 10(2): 1-41, 2010.

CANO, Wilson. Desequilíbrios regionais e concentração industrial no Brasil, 1930-1995. Campinas, SP: UNICAMP, IE, 1998. (30 anos de Economia - UNICAMP).

CARDOSO, Fernando Henrique. O Modelo Político Brasileiro e Outros Ensaios. Rio de Janeiro: Editora

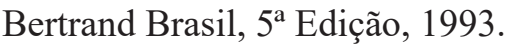

CATAIA, Marcio. A geopolítica das fronteiras internas na constituição do território: o caso da criação de novos municípios na região Centro-Oeste do Brasil durante o regime militar. Scripta Nova, Revista Electrónica de Geografía y Ciencias Sociales. Vol. X, n. 218 (22), agosto de 2006.

COX, Kevin R. Globalization, uneven development and capital: reflections on reading Thomas Friedman's The World Is Flat. Cambridge Journal of Regions, Economy and Society, p.1-22, 2008.

DIAS, Guilherme da Silva; AGUIRRE, Basília. Crise político-econômica: as raízes do impasse. In: SOLA, Lourdes (Org.). Estado, Mercado e Democracia. Política e economia comparadas. Rio de Janeiro: Paz e Terra, 1993

DRAIBE, Sonia. O Welfare State no Brasil: Características e Perspectivas. Caderno de Pesquisa n. 8, NEPP/UNICAMP, 1993.

EGLER, Claudio. Crise e Dinâmica das Estruturas Produtivas Regionais no Brasil. In: Castro, I.E; Gomes, P.C.C; Corrêa, R.L. (Org). Brasil: questões atuais da reorganização do território. Rio de Janeiro: Bertrand Brasil, 1996. 470p.

EGLER, Claudio. Questão Nacional e Gestão do Território no Brasil. In: Castro, I.E; Gomes, P.C.C; Corrêa, R.L. (Org). Geografia: conceitos e temas. 13 ${ }^{\mathrm{a}}$ ed. Rio de Janeiro: Bertrand Brasil, 2010. 352p.

FARIA, Luiz Augusto Estrella; WINCKLER, Carlos Roberto. O Andar do Crustáceo. Ensaios FEE, Porto Alegre, (15)2, 413-457, 1994.

FIORI, José Luís. Em busca do dissenso perdido: ensaios críticos sobre a festejada crise do Estado. Rio de Janeiro: Insight, 1995.

GONZÁLEZ, Sara. ¿Es la teoría de la regulación todavía relevante para la comprensión de la sociedad capitalista actual? Respuesta a Horacio Capel. Biblio 3W, Revista Bibliográfica de Geografía y Ciencias Sociales. Vol. IX, n 526, 5 de agosto de 2004

GUIMARÃES NETO, Leonardo. Antecedentes e Evolução do Planejamento Territorial no Brasil. In: FAVARETO, Arilson...[et al]. Políticas de desenvolvimento territorial rural no Brasil: avanços e desafios-Brasília: IICA, 2010. (Série Desenvolvimento Rural Sustentável; v.12).

JESSOP, Bob. State Power. Cambridge: Polity Press, 2008.

JESSOP, Bob. A regulationist and state-theoretical analysis. In: BOYD, Richard and NGO, Tak-Wing (Ed). Asian States: Beyond the Developmental Perspective. London, [UK] ; New York : Routledge Curzon, 2005.

JESSOP, Bob; SUM, Ngai-Ling. Beyond the regulation approach: putting capitalist economies in their place. Cheltenham: Edward Elgar, 2006, 479p

IGLESIAS, Enrique V. El papel del Estado y los paradigmas económicos en América Latina. Revista de la Cepal n. 90, dez 2006.

KLINK, J. J. ; DENALDI, R. . On financialization and state spatial fixes in Brazil. A geographical and historical interpretation of the housing program My House My Life. Habitat International, v. 44, p. 220-226, 2014. LEFEBVRE, Henri. A Re-Produção das Relações de Produção. Porto: Publicações Escorpião, 1973.

LESSA, Carlos. A Estratégia de Desenvolvimento 1974/76: sonho e fracasso. Campinas: Editora do IE/ Unicamp, 1998

LOPREATO, Francisco. O endividamento dos governos estaduais nos anos 90. Economia e Sociedade, Campinas, (15): 117-158, dez. 2000.

MARTINS, Herbert. A Fragmentação do Território Brasileiro: a criação de novos estados no Brasil. Caderno CRH, Salvador, n. 35, p. 263-288, jul./dez. 2001 
NABUCO, Maria Regina. A (des)institucionalizacão das políticas regionais no Brasil. etc, espaço, tempo e crítica. Revista Eletrônia de Ciências Humanas e Sociais e outras coisas. Setembro de 2007, n 2 (6), vol. 1. OLIVEIRA, Fabrício Augusto de. A reforma tributária de 1966 e a acumulação de capital no Brasil. São Paulo: Editora Brasil Debates, 1981.

OLIVEIRA, Francisco de. Elegia Para uma Re(li)gião. Sudene, Nordeste. Planejamento e Conflito de Classes. Rio de Janeiro: Paz e Terra, 1981 b.

OLIVEIRA, Francisco de. A Metamorfose da Arribaçã: fundo público e regulação autoritária na expansão econômica do Nordeste. Novos Estudos Cebrap, n.27, 1990.

OOSTERLYNCK, Stjin. Regulating Regional Uneven Development and the Politics of Reconfiguring Belgian State Space. Antipode, 42: 1151-1179, 2010

RODRIGUEZ, Vicente. Os Interesses Regionais e a Federação Brasileira. Ensaios FEE, Porto Alegre, (15)2, 338-352, 1994.

SALLUM JR., Brasilio. Federação, autoritarismo e democratização. Tempo Social, Revista de Sociologia da USP, 8(2): pp. 27-52, out. 1996.

IGLESIAS, Enrique V. El papel del Estado y los paradigmas económicos en América Latina. Revista de la Cepal n. 90, dez 2006.

SADDI, Fabiana. Política e economia no federalismo do governo Geisel. Revista de Economia Política, vol. 23, n 2 (90), abril-junho/2003

SOUZA, Celina. Regiões Metropolitanas: condicionantes do regime político. Lua Nova n.59, 2003.

SOUZA, Maria Adélia A. de. O II PND e a política urbana brasileira: uma contradição evidente. In: DEÁK, Csaba; SCHIFFER, Sueli Ramos (orgs.). O processo de urbanização no Brasil. São Paulo: Edusp, 2004.

Submitted 21 september 2016

Accepted 21 october/ 2016 